\title{
Students' Communication Skills in Junior High School
}

\author{
Anggi Idwar Pratama*, Budi Astuti \\ Guidance and Counseling, Postgraduate Program, Yogyakarta State University, Yogyakarta, Indonesia
}

Received July 24, 2020; Revised October 18, 2020; Accepted October 24, 2020

\section{Cite This Paper in the following Citation Styles}

(a): [1] Anggi Idwar Pratama, Budi Astuti , "Students' Communication Skills in Junior High School," Universal Journal of Educational Research, Vol. 8, No. 12, pp. 6798 - 6807, 2020. DOI: 10.13189/ujer.2020.081246.

(b): Anggi Idwar Pratama, Budi Astuti (2020). Students' Communication Skills in Junior High School. Universal Journal of Educational Research, 8(12), 6798 - 6807. DOI: 10.13189/ujer.2020.081246.

Copyright $\bigcirc 2020$ by authors, all rights reserved. Authors agree that this article remains permanently open access under the terms of the Creative Commons Attribution License 4.0 International License

\begin{abstract}
This study aims to obtain an objective picture and information about students' communication skills in school. The research method uses quantitative descriptive methods with library studies' support, strengthening researchers' analysis in making conclusions following the subject matter-the data collection techniques using the Likert scale model. The communication skills questionnaire consisted of 4 indicators and 36 statement items. The Cronbach alpha coefficient of the entire scale calculated was 0.788 . Because the scale factor and the reliability coefficient are high, the scale can be considered reliable, and the scale items are homogeneous. Communication skills scale distributed using Google forms. The research sample was 134 grade VII students of Al Azhar 26 Yogyakarta Islamic Middle School in 2019/2010. It consisted of seven classes, namely VII A, VII B, VII C, VII D, VII E, VII F, and VII G. The result showed that students' communication competency of indicators were in the medium category (71\%). Communication barriers indicators were in a low category (67\%). Meanwhile, body language communication got a low score (65\%), and $77 \%$ of students have a low emotional maturity score in communication indicators. Overall, students' communication skills of class VII were classified as moderate (62\%). The result show there was no significant difference in communication significance between male or female. Both male and female students have communication skills that are not good enough. Students' communication skills need to be improved by the teacher's guidance and counseling or counselor using guidance and counseling methods, such as discussion and other related methods.
\end{abstract}

Keywords Communication Skills, 21st Century, Guidance, Counseling

\section{Introduction}

According to the general provisions law of Republic Indonesia [1] concerning the National education system, students are a member of the community who is trying to develop their potential through a learning process that is available at certain levels, levels, and types of education. From the psychological perspective, students are individuals in the process of growth and development both physically and psychologically according to their nature. As individuals growing and developing, students need guidance and direction consistent towards the optimal point of their natural ability [2].

Students are individuals who are in the process of growing and developing their potential. It requires much guidance to develop their potential and skills. The 21st century is a century of increasingly broad science and technology. The more comprehensive development of science causes each student to master cognitive abilities and master communication skills. In the 21st century, communication skills are essential to support marketability, employability, and citizenship readiness. [3].

Wagner [4] and the Change Leadership Group of Harvard University identified the competencies and survival skills needed by students to deal with life in the 21st century, emphasizing seven skills that include communication skills both orally and in writing. Communication skills can support other skills needed by students. The government's reason for developing a curriculum to gain future competencies is even the ability to communicate.

Communication skills have a very significant 
relationship with learning activities. If students have better communication skills, they will have better learning activities. Conversely, if students do not have excellent communication skills, it will cause less learning activities [5]. Communication skills affect student achievement by $74.7 \%$ [6]. Students need communication skills in the community because students are part of social life [7]; when students have entered the workplace to communicate work-related to complaints, following their job descriptions, communication skills function to control and improve communication [8].

Communication skills are essential possessed by students, so we need to analyze student communication skills. The analysis attempts to decompose a problem or focus of study into parts (decomposition) so that the structure/order of a decomposed form appears clearly and, therefore, can be more clearly captured meaning or more clearly understood [9].

The study aimed to determine students' communication skills, especially students in grade VII junior high school. This grade VII was a transition from elementary to junior high school when students had a new environment and new friends; communication skills were needed in adjusting to something new. Communication skills are critical for students to have; communication skills can be used anytime and anywhere until students enter work later. Analysis can also help teacher guidance and counseling to provide guidance and counseling services to improve students' communication skills.

Communication skills are measured as a whole. According to the scale's indicators, of the four indicators: (1) Communication competence, which consists of matters relating to feelings, confidence, expressing ideas, providing information, explaining, and using language structures are good and right. (2) Communication barriers, such as fear, anxiety, shame, and always wanting to satisfy others. (3) Body language, non-verbal communication, (4) Emotional maturity in communication, mutual respect, trust, and tolerance between the sender and receiver. With this research, it is hoped that it can help the guidance and counseling teacher provide excellent services.

\section{Methods}

\subsection{Research Design}

The research method used is a descriptive quantitative approach supported by a literature study to follow the main problem. Descriptive analysis aims to describe the data from variables obtained from the research subjects [10]. Quantitative research methods are research methods based on the philosophy of positivism, used to examine specific populations or samples, data collection using research instruments, quantitative/statistical data analysis [11]. A literature study is a data collection technique by surveying reviewers of books, literature, records, and reports related to the problem being solved [12].

\subsection{Data Collection}

The data collection methods in this research used a communication skills scale instrument adapted from the Communication Skills Scale (CSS) developed by Akkuzu and Akkaya [13]. The scale has been validated used item analysis, Explanatory Factor Analysis (CFA), and Confirmatory Factor Analysis (CFA) to obtain structural validity. On the EFA stage, there were 36 valid items with an item-total test correlation coefficient between 0,311 and 0,594. The CFA stage proposes four CSS factors, namely competence, discouragement, body language, and dignification. The first factor is "competence," which consists of 12 items related to self-confidence in affective, consciousness, and linguistics areas. The items in this factor have factor loading values between 0,507 and 0,741. The second factor labeled as "discouragement," which consistt13 items related to problems during the communication process, include students' inability to transmit their feelings and thoughts accurately to receivers. The items in discouragement factors have factor loads of value between 0,500 to 0,699 . The third factor was "body language," which consists of five items with factor load values between 0,588 and 0,699 - the items on this factor related to behavioral forms when students communicate with others. The fourth factor was "dignification," consisting of six items with factor load values between 0,500 and 0,722 -all items related to the importance of mutual feelings and the communication process's ideas.

The CFA analysis found that t-values of all items were greater than 2,56, with a significant value of 0,01 . The error variance was low, and the model fit was acceptable. Based on the results, the four factors can be used as indicators of the Communication Skills Scale. The instrument also had a reliability Cronbach's Alpha score of 0.788 . The items of each factor can be seen in table 1 . 
Table 1. Communication Skills Scale items

\begin{tabular}{|c|c|c|}
\hline No. & Indicator & Items \\
\hline 1 & \multirow{13}{*}{ Competence } & When I make a presentation in front of the community, I feel confident \\
\hline 2 & & When I make a speech, I trust myself \\
\hline 3 & & $\begin{array}{l}\text { I believe that I can understand what people say clearly and } \\
\text { correctly }\end{array}$ \\
\hline 4 & & I can express my feelings and thoughts clearly in front of the community \\
\hline 5 & & I can talk easily to my teachers as well as my friends \\
\hline 6 & & When I talk, I pay attention to stress and intonation rules \\
\hline 7 & & I believe that I speak in a specific order and logic \\
\hline 8 & & When I talk to someone, I convince them \\
\hline 9 & & I think I use rich vocabulary during oral communication \\
\hline 10 & & The person to whom I talk wants to collaborate with me. \\
\hline 11 & & I believe that I am good at meeting the expectation of the people I talk \\
\hline 12 & & I speak fluently during communication \\
\hline 13 & & I cannot choose words carefully during the speech \\
\hline 14 & \multirow{12}{*}{ Discouragement } & I cannot behave naturally during the speech \\
\hline 15 & & I cannot focus on the topic at the time of the speech \\
\hline 16 & & I fail at the communication of my thoughts and feelings to people \\
\hline 17 & & It is hard for me to express my thoughts \\
\hline 18 & & While talking, I use in unnecessary words \\
\hline 19 & & Listeners can hardly hear me when I talk \\
\hline 20 & & I jump from topic to topic without communication \\
\hline 21 & & Listeners having different ideas makes me uncomfortable \\
\hline 22 & & I am worried about choosing the correct word \\
\hline 23 & & Sometimes people cannot understand me because I swallowed the last words when I speak \\
\hline 24 & & I am afraid of being ridiculed when you say my thoughts \\
\hline 25 & & I am afraid of encountering negative thoughts \\
\hline 26 & \multirow{5}{*}{ Body language } & While listening to someone, I use fillers \\
\hline 27 & & While listening to someone, I keep the eye contact \\
\hline 28 & & I show my approval by nodding \\
\hline 39 & & I use body language during a speech \\
\hline 30 & & While I am speaking, I want listeners to show me listen to me \\
\hline 31 & \multirow{6}{*}{ Digniffication } & I prefer monologues rather than dialogues. \\
\hline 32 & & I am open to criticism while speaking \\
\hline 33 & & I want people to respect my ideas \\
\hline 34 & & I expect people to be sincere while talking \\
\hline 35 & & I think I am a good listener because I perceive what is said accurately and completely \\
\hline 36 & & I think I understand the situation she/he is in while she/he is speaking. \\
\hline
\end{tabular}

\subsection{Subject of Study}

The research subjects in this study were seventh-grade students of $\mathrm{Al}$ Azhar Islamic Junior High School 26 Yogyakarta in the academic year 2019/2020, consisting of seven classes with 134 respondents.

There are several processes in this research. They started by preparing the letters needed, preparing a research tool in the form of a scale agreed upon by the supervisor, then conducting a trial to determine whether the statement used is understood by respondents and measures what the researcher wants to measure. After the preparatory phase is completed, the researcher then continues with the research data collection using Google forms.

\section{Results}

Students communicate with others in all activities: at school, home, the community, or even in the workplace. Communication is a social process where individuals use symbols to create and interpret meanings in the environment [14]. Communication requires skills when students want to communicate with the teacher; students must not communicate carelessly but need a way to convey. Skills are mostly the way for someone to do something [15]. Communication skills are a process of delivering information where the success of communication depends on the design of the message or data and how to give it [16]. The following results of the overall analysis of communication skills scale: 
Table 2. Communication Skill Scale

\begin{tabular}{|c|c|c|c|c|}
\hline \multirow{2}{*}{ Variable } & \multirow{2}{*}{ Score } & \multirow{2}{*}{ Category } & \multicolumn{2}{|c|}{ Subject } \\
\hline & & & $\mathbf{F}$ & Percentage \\
\hline \multirow{5}{*}{$\begin{array}{c}\text { Communication } \\
\text { Skills }\end{array}$} & $X \leq 72$ & Very low & 2 & $1 \%$ \\
\hline & $\begin{array}{c}72<X \leq \\
96\end{array}$ & Low & 48 & $36 \%$ \\
\hline & $\begin{array}{c}96<X \\
\leq 120\end{array}$ & Medium & 83 & $62 \%$ \\
\hline & $\begin{array}{c}120 \mathrm{X} \leq \\
144\end{array}$ & High & 1 & $1 \%$ \\
\hline & $144<X$ & $\begin{array}{l}\text { Very } \\
\text { high }\end{array}$ & 0 & $0 \%$ \\
\hline Total & & & 134 & $100 \%$ \\
\hline
\end{tabular}

The results of the overall analysis, communication skills of 134 students from 83 students into the medium category (62\%), two students into the very low group (1\%), 48 students included in the low category (36\%), one student entered into the high category (1\%) and 0 entered into the very high category $(0 \%)$. The results prove that students' communication skills need to be increased; of the 134 students, only one student has high communication skills. The chi-square analysis also proved that there was no difference in communication skills between male and female students.

Table 3. The result of chi-square analysis

\begin{tabular}{|c|c|c|}
\hline Variable & $\begin{array}{c}\text { Pearson } \\
\text { chi-square }\end{array}$ & $\begin{array}{c}\text { Asymp.sig } \\
\text { 2-sided }\end{array}$ \\
\hline Gender*Communication Skills & 1,496 & 0,683 \\
\hline
\end{tabular}

The results showed the asymp sig.2-sided value $0.683>$ 0.05 , which means that there is no relationship between gender and students' communication skills. Both male and female students have relatively the same communication skills, which are as follows table 4 .

The table shows that male and female students have communication skills in the very low category. In the low category, the difference between male and female students is seven people. In contrast, in the medium and high categories, the difference between male and female students is only one student. This study indicates that male and female students have almost the same communication skills; both female and male students have communication skills in the low and medium categories. After the overall analysis, the scale is analyzed based on four indicators of communication skills, presented as follows:

Table 4. Gender and Communication Skills cross-tabulation

\begin{tabular}{|c|c|c|c|c|c|}
\hline & \multicolumn{4}{|c|}{ Communication_skills } & Total \\
\hline & Very low & Low & Medium & High & \\
\hline Male & 1 & 21 & 41 & 1 & 64 \\
\hline Female & 1 & 27 & 42 & 0 & 70 \\
\hline & 2 & 48 & 83 & 1 & 134 \\
\hline
\end{tabular}

\subsection{Communication Competence of Students}

When communicating, students need competence. Competence is an attribute to attach superior quality human resources; attribute refers to specific characteristics required to effectively carry out work [17]. Competence needs to be owned by students when communicating. Communication competence consists of matters relating to students' feelings of confidence in expressing ideas, completing assignments virtually, providing information well, explaining correctly, and using language structure that is good and right. Following is the result of the analysis of students' communication competence:

Table 5. Communication Competence

\begin{tabular}{|c|c|c|c|c|}
\hline \multirow{2}{*}{ Indicator } & \multirow{2}{*}{ Score } & Category & F & Percentage \\
\cline { 2 - 5 } & & & 4 & $3 \%$ \\
\hline \multirow{3}{*}{ Communication Competence } & $\mathrm{X} \leq 24$ & Very low & 43 & $32 \%$ \\
\cline { 2 - 5 } & $24<\mathrm{X} \leq 32$ & Low & 71 & $53 \%$ \\
\cline { 2 - 5 } & $32<\mathrm{X} \leq 40$ & Medium & 16 & $12 \%$ \\
\cline { 2 - 5 } & $40 \mathrm{X} \leq 48$ & High & 0 & $0 \%$ \\
\hline
\end{tabular}


From the table above, it can be concluded that the communication competence of students from 134 students is 71 students in the moderate category (53\%), four students in the deficient category (3\%), 43 students in the low category (32\%), 16 students high category (12\%) and 0 students in the very high category $(0 \%)$. Nearly half of the students are in the medium category in communication competence. The chi-square analysis also proved that there was no difference in communication skills between male and female students.

Table 6. Gender and competence chi-square analysis

\begin{tabular}{|c|c|c|}
\hline Variable & $\begin{array}{c}\text { Pearson } \\
\text { chi-square }\end{array}$ & $\begin{array}{c}\text { Asymp.sig } \\
\text { 2-sided }\end{array}$ \\
\hline $\begin{array}{c}\text { Gender*Communication } \\
\text { Competence }\end{array}$ & 1,668 & 0,644 \\
\hline
\end{tabular}

The results showed that the asymp sig.2-sided value was $0.644>0.05$, which meant no relationship between gender and communication competence. Both male and female students have equal communication competencies as follows:

Table 7. Gender and competence cross-tabulation

\begin{tabular}{|c|c|c|c|c|c|}
\hline & \multicolumn{4}{|c|}{ Communication_competence } & \multirow[t]{2}{*}{ Total } \\
\hline & Very low & Low & Medium & High & \\
\hline Male & 2 & 19 & 33 & 10 & 64 \\
\hline Female & 2 & 24 & 38 & 6 & 70 \\
\hline & 4 & 43 & 71 & 16 & 134 \\
\hline
\end{tabular}

The table shows that male and female students have competence in the very low category, namely two students. In the low and medium categories, the difference between male and female students is five people. Meanwhile, in the high category, men have a more significant proportion than women, namely ten people. This study indicates that the difference between male and female students in the competence indicator is not too much and tends to have almost the same abilities. Both male and female students still need to improve communication competency.

\subsection{Communication Barriers}

Communication barriers mean something that prevents students when communicating. Communication barriers result in students unable to unleash their potential and prevent them from effectively giving or receiving messages. According to [18], communication barriers refer to everything that can distort the news or receiving messages. Following the results of the analysis of students' communication barriers.

From the table 8, communication barriers 134 students 67 students in the low category (50\%), eight students in the very low category (6\%), 51 students in the moderate category (38\%), eight students in the high category (6\%) and no learners in the very high category $(0 \%)$. The result of the chi-square analysis showed that there was no relationship between gender and students' communication skills.

The results showed that the asymp sig.2-sided value was $0.644>0.05$, which meant no relationship between gender and communication competence. Gender does not make male students have more barriers than female students or vice versa. Both male students and female students have the same tendency to communicate. Women and men can experience communication barriers in carrying out communication in everyday life.

Table 8. Barriers to the communication of students

\begin{tabular}{|c|c|c|c|c|}
\hline \multirow{2}{*}{ Indicator } & \multirow{2}{*}{ Score } & Category & \multicolumn{2}{|c|}{ Subject } \\
\cline { 2 - 5 } & & & \multicolumn{2}{c|}{ Percentage } \\
\hline \multirow{4}{*}{ Communication barriers } & $\mathrm{X} \leq 26$ & Very low & $6 \%$ \\
\cline { 2 - 5 } & $26<\mathrm{X} \leq 35$ & Low & 67 & $50 \%$ \\
\cline { 2 - 5 } & $35<\mathrm{X} \leq 43$ & Medium & 81 & $38 \%$ \\
\cline { 2 - 5 } & $43 \mathrm{X} \leq 52$ & High & 0 & $0 \%$ \\
\cline { 2 - 5 } & $52<\mathrm{X}$ & Very high & 134 & $100 \%$ \\
\hline
\end{tabular}

Table 9. Gender and communication barriers chi-square analysis

\begin{tabular}{|c|c|c|}
\hline Variable & Pearson chi-square & Asymp.sig 2-sided \\
\hline Gender*Communication barriers & 1,668 & 0,644 \\
\hline
\end{tabular}


Table 10. Body language communicates

\begin{tabular}{|c|c|c|c|c|}
\hline \multirow{2}{*}{ Variable } & \multirow{2}{*}{ Score } & \multirow{2}{*}{ Category } & \multicolumn{2}{|c|}{ Subject } \\
\cline { 3 - 5 } & & & F & Percentage \\
\hline \multirow{3}{*}{ Body language communicates } & $\mathrm{X} \leq 11$ & Very low & 18 & $13 \%$ \\
\cline { 2 - 5 } & $11<\mathrm{X} \leq 14$ & Low & 87 & $65 \%$ \\
\cline { 2 - 5 } & $16<\mathrm{X} \leq 17$ & Medium & 28 & $21 \%$ \\
\cline { 2 - 5 } & $17 \mathrm{X} \leq 20$ & High & 1 & $0 \%$ \\
\cline { 2 - 5 } & $20<\mathrm{X}$ & Very high & 134 & $100 \%$ \\
\hline
\end{tabular}

\subsection{Body Language Communicates}

Body language is a way for students to express faces, eyes, and body posture in communication or nonverbal communication. Eye contact has two functions in communication. First, the regulatory role tells others whether they will communicate with that person or avoid it. Both expressive purposes, namely to say to others how they feel about them while the body posture is often symbolic, tend to over-appreciate tall and balanced people. Even the way of sitting, standing, and lying down can communicate a limited but exciting set of meanings [19]. Next is the analysis of communicating body language used by students.

From the table 10, it can be concluded that 87 students have body language when communicating in the low category (65\%), 18 students in the very low category (13\%), 28 students in the moderate category (21\%), one student included in the high category (1\%). The third indicator shows no students involved in the very high category $(0 \%)$. Nearly half of the students fall into the low category in using nonverbal communication or body language. There is a result of chi-square analysis of gender and body language indicators.

Table 11. Gender and body language chi-square analysis

\begin{tabular}{|c|c|c|}
\hline Variable & $\begin{array}{c}\text { Pearson } \\
\text { chi-square }\end{array}$ & $\begin{array}{c}\text { Asymp.sig } \\
\text { 2-sided }\end{array}$ \\
\hline Gender*Body language & 6,397 & 0,094 \\
\hline
\end{tabular}

The results showed that the asymp sig.2-sided value was $0.094>0.05$, which meant no relationship between gender and body language indicator. Gender does not cause a man or woman to have better body language skills than others.
The cross-tabulation between gender and body language is as follows:

Table 12. Gender and body language cross-tabulation

\begin{tabular}{|c|c|c|c|c|c|}
\hline & \multicolumn{4}{|c|}{ Body language } & \multirow[t]{2}{*}{ Total } \\
\hline & $\begin{array}{l}\text { Very } \\
\text { low }\end{array}$ & Low & Medium & High & \\
\hline Male & 10 & 46 & 8 & 0 & 64 \\
\hline Female & 8 & 41 & 20 & 1 & 70 \\
\hline & 18 & 87 & 28 & 1 & 134 \\
\hline
\end{tabular}

The table 12 shows that even though male and female students have almost the same body language skills, there are relatively large differences in several categories. Male students had a more significant proportion of female students in the low and very low categories. In contrast, female students had a higher proportion in the medium category, with a difference of up to 12 students. In fact, in the high category, there is only one student, namely a female student. Although the chi-square analysis results show no relationship between gender and body language, the proportion of female students who have moderate and high body language skills is higher than that of boys.

\subsection{Emotional Maturity in Communication}

Emotional maturity is individuals' ability to be tolerant, feel comfortable, have self-control, be willing to accept themselves and others, and express their emotions constructively and creatively [20]. A person who reaches emotional maturity can control his emotions well, think well, and objectively [21]. The following analysis of emotional maturity in communicating students. 
Table 13. The emotional maturity of communication

\begin{tabular}{|c|c|c|c|c|}
\hline \multirow{2}{*}{ Indicator } & \multirow{2}{*}{ Score } & \multirow{2}{*}{ Category } & \multicolumn{2}{|c|}{ Subject } \\
\cline { 2 - 4 } & & Fercentage \\
\hline \multirow{4}{*}{ Emotional Maturity } & $\mathrm{X} \leq 12$ & Very low & 5 & $6 \%$ \\
\cline { 2 - 5 } & $26<\mathrm{X} \leq 16$ & Medium & 26 & $50 \%$ \\
\cline { 2 - 5 } & $35<\mathrm{X} \leq 20$ & High & 0 & $38 \%$ \\
\cline { 2 - 5 } & $43 \mathrm{X} \leq 24$ & Very high & 0 & $6 \%$ \\
\cline { 2 - 5 } & $24<\mathrm{X}$ & & 134 & 03 \\
\hline
\end{tabular}

From the table above, it can be concluded that 103 students have emotional maturity in communication in the low category (77\%), five students included in the very low category (4\%), 26 students in the moderate category (19\%), 0 participants students in the high category $(0 \%)$ and 0 students in the very high category $(0 \%)$. The chi-square analysis also proof that there was no difference in communication skills between male and female students.

Table 14. Gender and emotional maturity chi-square analysis

\begin{tabular}{|c|c|c|}
\hline Variable & $\begin{array}{c}\text { Pearson } \\
\text { chi-square }\end{array}$ & $\begin{array}{c}\text { Asymp.sig } \\
\text { 2-sided }\end{array}$ \\
\hline $\begin{array}{c}\text { Gender*Emotional } \\
\text { Maturity }\end{array}$ & 0,408 & 0,816 \\
\hline
\end{tabular}

The results showed that the asymp sig.2-sided value was $0.816>0.05$, which means no relationship between gender and students' emotional maturity. Male students do not have better emotional maturity than female students and vice versa. Both male and female students have equal emotional maturity. Many students do not have the emotional maturity to communicate well-the teacher needs to improve students' communication skills.

\section{Discussion}

Communication skills can not be separated from students, especially in the learning process; students must convey ideas, respect others' opinions, listen to the teachers' explanation, and listen to friends' arguments when discussing. Many students make active learning ambiance because they can express opinions, and students can respect others' views. Communication skills can increase the confidence of students. The better students' communication skills, the better their learning activities. Conversely, if students have poor communication skills, their learning activities will be less enjoyable [26,27].

Communication skills affect the learning achievement of students by $74.7 \%$ [28]. There are many benefits to communication skills for students. To find out the communication skills of students, the researchers conducted an analysis. Overall analysis results, from 134 students, 83 students were included in the medium category (62\%), 48 students were involved in the low category (36\%), one student included in the high category (1\%). From the analysis results, it is clear that many students do not have communication skills. The data analysis results show that there is no difference between male and female students in communication skills. Boys and girls in this school have almost the same communication skills; the only difference is the strategy or communication type. According to [42], men's communication patterns tend to be direct, factual, and honest. At the same time, women avoid direct conversations and speak softly and use certain tactics to make others understand the meaning of what they say. Women use communication to establish social relationships and build connections with others, while men use communication to exchange information and solve problems. Even though they have different ways and patterns of communication, the communication skills of men and women in Al-Azhar Middle School Yogyakarta tend to be the same, and there is no significant difference in ability levels.

Then after the overall analysis, the scale of students' communication skills is analyzed in each indicator. The first indicator of communication competence consists of matters relating to personal feelings of confidence, expressing ideas, completing tasks effectively, providing information well, explaining well, and using language structure that is good and right. Having communication competence makes students have the ability to ask questions, the ability to answer questions, the ability to raise opinions, and the ability to respond to views [29]. Communication competence can also increase communication motivation related to students' willingness to approach or avoid communication with others. Communication skills include speaking, hearing, seeing, and expressing messages verbally in certain situations [30]. The analysis of 134 students showed that 71 students were in the moderate category (53\%). There are only 16 students who received a high category (12\%). The result shows that there is no significant difference in competence between male and female students. Women and men have almost the same communication skills; the only difference is the type of communication chosen. Male students generally prefer to speak directly, while female students are more comfortable communicating through writing. The result follows the research [42] that male students have a higher percentage of speaking directly because they think the conversation is more effective and faster to convey ideas. Meanwhile, women prefer to communicate through writing 
because they are considered safer and have less risk. Even though they have different communication types, male and female students have almost the same communication skills, so there is no significant difference between them.

The second indicator of communication barriers occurs because of individual internal factors, such as Perceptual Distortion, a narrow perspective on oneself, and differences in thinking and ways of understanding that are narrow towards others [31]. Obstacles also include joking, not paying attention to the teacher, emotional mood unstable, and bored with the lesson [32]. The results show that 67 students in the low category (50\%), 51 students in the moderate category (38\%). Eight students in the high category $(6 \%)$ or other words still have communication obstacles. The barriers will make successful communication not realized; it can cause restrictions for communicators and their communicants [33]. The result shows that male and female students have the same obstacles in the communication process. Common obstacles in communicating include difficulties in negotiating or resolving conflicts. In general, students have understood the importance of good communication in interacting but often have difficulty negotiating or dealing with conflicts with other people [40]. It proves that communication skills need to be improved again so that there are no more barriers to communication owned by students. This study's results follow the research results [37] that there is no significant difference between self-efficacy to communicate for male and female students. Both have obstacles in anxiety and fear of being wrong when communicating with others.

The third indicator of communication skills is body language. Students do not just rely on verbal communication but also depend on non-verbal communication or body language. Non-verbal communication has a function as Repetition, Substitution, Contradiction, Complement, and Accreditation [34]. Non-verbal communication has many features, can even replace verbal communication, emphasize or complement, repair, regulate verbal behavior, and show contradictions [35]. Nonverbal communication occupies a significant portion. Many verbal communications are not effective because they do not use nonverbal communication when communicating [36]. The analysis of body language indicators shows that 87 students in the low category (65\%). The result shows that students' body language needs to be improved when communicating to optimize students' communication skills. Although the chi-square analysis results show no relationship between gender and body language, the proportion of female students who have moderate and high body language skills is higher than boys. This study's results are consistent with the research [41] that women are better at expressing feelings and thoughts through eye contact, smiles, and body movements when communicating. On the other hand, male students tend to be more rigid and rarely use body language in the communication process.

The fourth indicator is emotional maturity. Building excellent communication starts with mutual respect, trust, and tolerance. Emotional Maturity 134 students 103 students in the low category (77\%). The low emotional maturity of communication will make students throw inappropriate words, such as insulting friends when discussing and saying dirty words with friends. Students also give inadequate responses, such as passive listening to the teacher when explaining the subject matter and ignoring friends when talking, blaming friends if there are problems in class, and cornering friends if they make mistakes [24]. Both male and female students have low emotional maturity. Emotional maturity can be defined as a person's ability to control his feelings and behavior in undesirable situations, adapt to peers, and respond according to what is expected by the surrounding environment. Emotional maturity can be influenced by parenting styles, culture, and the individual's environment [43].

The results show that students' communication skills need to be improved. Communication skills are indispensable in the 21st century because of many works and the human need to communicate at work and live daily life in society. If students do not have good communication skills, they will experience difficulties carrying out work and interacting with other people. Guidance and Counseling Teachers can develop various services to improve communication skills through classical guidance services. According to [38], the environment and classroom atmosphere can affect students' communication skills and collaborative learning by creating a classroom atmosphere where students can participate and interact well. If students can interact well, they will get used to communicating with other people and improving their communication skills. Guidance and counseling teachers can also provide group discussion techniques to improve students' communication and analysis skills on a problem. This service follows the opinion [39] that communication skills can be trained by providing students opportunities to discuss strategies in solving a problem. Students will be able to practice the courage to speak in public and express their ideas to others. If students already have good communication skills, they will have sufficient provisions to compete and survive this 21st century.

\section{Conclusions}

Based on the analysis results as a whole, students' communication skills are classified as moderate. Then the communication skills scale were analyzed based on four indicators, (1) Indicators of communication competence of students were classified as moderate, (2) Barriers to the communication of students were classified as low, (3) body language of communication was classified as low, (4) 
emotional maturity of communication was classified as low. The validity and reliability of the communication skills Cronbach's Alpha score of 0.788. The communication skills of students must be improved. It is expected that the results of this study can be used as a reference for guidance and counseling teachers because communication skills are used to survive in the 21st century.

\section{Acknowledgments}

This research is part of a master's thesis research grant. The publication of the results presented has received funding from the directorate of Research and Community Service, the Directorate General of Research and Development of the Ministry of Research, Technology, and Higher Education. In project number: 058/SP2H/LT/DRPM/2020, thank you to the supervisor who has helped complete this article.

\section{REFERENCES}

[1] Undang-undang Republik No. 20. Tahun 2003. Tentang sistem pendidikan Bab 1 pasal 1 no 4.

[2] Desmita, Psikologi Perkembangan peserta didik Bandung: PT.Remaja Rosdakarya., 2012.

[3] C. Fadel. $21^{\text {st }}$ Century Skills: How can you prepare a student for the new Global Economy?. COSCO: Paris, 2008.

[4] T. Wagner. Overcoming The Global Achievement Gap (Online). Cambridge, Mass, Harvard University, 2010.

[5] S. Maryanti, Zikra, Nurfarhanah. Hubungan Antara Keterampilan Komunikasi dengan Aktiitas Belajar Siswa. Konselor, Vol. 1, No. 2, 2012.

[6] M. Noviyanti. Pengaruh Motivasi Dan Keterampilan Berkomunikasi Terhadap Prestasi Belajar Mahasiswa Pada Tutorial Online Berbasis Pendekatan Kontekstual Pada Matakuliah Statistika Pendidikan. Jurnal Pendidikan, Vol. 12, No.2, 80-88, 2011.

[7] W. M. Laksana. Psikologi Komunikasi; Membangun Komunikasi yang Efektif Dalam Interaksi Manusia. Bandung : Pustaka Setia, 2015.

[8] P. Robbins, Stephen, Judge, A. Timothy. Organizational Behaviour, Edisi 13, Jilid 1, Salemba Empat: Jakarta, 2017.

[9] A. Komariah, D. Satori. Metedologi Penelitian Kualitatif. Bandung : Alfabeta, 2014.

[10] S. Azwar. Metode Penelitian Psikologi (Edisi II). Yogyakarta: Pustaka Pelajar, 2019.

[11] Sugiyono. Metode Penelitian Kuantitatif Kualitatif dan R\&D. Bandung: Alfabeta, 2012.

[12] M. Nazir. Metode Penelitian. Bogor : Ghalia Indonesia, 2013.
[13] N. Akkuzu, N. Akkaya. Development and validity-reliability study of communication skills scale for student teachers: suggestion of an alternative model. Electronic Turkish studies-international periodical for the languages, literature, and history of Turkish or Turkic, Vol. 9, No. 8, 111-132, 2014.

[14] W. Richard, L. H. Turner. Pengantar Teori Komunikasi Analisis dan Aplikasi Edisi 3. Jakarta: Salemba Humanika, 2008.

[15] A. Sutardi, E. Budiasih. Mahasiswa Tidak Memble Siap Ambil Alih Kekuasaan Nasional, Jakarta : PT. Elex Media Komputido, 2010.

[16] A. Majid, C. Rochman. Pendekatan Ilmiah dalm Implementasi Kurikulum 2013. Bandung: PT Remaja Rosdakarya, 2014.

[17] Sudarmanto. Kinerja dan Pengembangan Kompetensi SDM. Yogyakarta: Pustaka Pelajar, 2009.

[18] J. A. Devito. Interpersonal Communication. New York: Harper Collins College Publisher, 2009.

[19] J. Fiske. Pengantar Ilmu Komunikasi, Jakarta:Rajawali pers. 2012.

[20] Y. Syamsu. Psikologi Perkembangan anak dan remaja. Bandung : PT. Remaja Rosdakarya, 2006.

[21] B. Walgito. Pengantar Psikologi Umum. Jakarta: Penerbit Andi, 2004.

[22] D. P. Utomo, H. Harmiyanto. Hubungan Keterampilan Komunikasi Interpersonal dan Kepercayaan Diri Siswa Kelas X SMAN 1 Garum Kabupaten Blitar. Jurnal Kajian Bimbingan dan Konseling. Vol .1, No.2,. 55-59, 2016.

[23] M. Rasuly. Hubungan antara tingkat kepercayaan diri dan penerimaan diri dengan keterampilan komunikasi interpersonal siswa kelas XI SMK Negeri Se-Kota Pamekasan, Skirpsi Jurusan Bimbingan dan Konseling Psikologi-fakultas Ilmu Pendidikan UM, 2012

[24] S. Kartianti. Hubungan Kepercayaan Diri dengan Keterampilan Berkomunikasi Siswa SMA. Seri Ilmu-ilmu sosial dan Kependidikan. Vol. 3, No.2, 71-75, 2019.

[25] K. M. Mollah. Kepercayaan Diri dalam Peningkatan Keterampilan Komunikasi, Jurnal Pemikiran dan Pendidikan Islam. Vol .9, No.1,2019.

[26] A. Wilhalminah, U. Rahman, M. Muchlisah. Pengaruh keterampilan komunikais terhadap perkembangan moral siswa pada pada pelajaran bilogi kelas XI IPA SMA Muhammadiyah Limbung. Jurnal Biotek. Vol.5,No.2,2017.

[27] S. Maryanti, Zikra, Nurfarhanah. Hubungan Antara Keterampilan Komunikasi dengan Aktiitas Belajar Siswa. Konselor, Vol. 1, No. 2, 2012.

[28] M. Noviyanti. Pengaruh motivasi dan keterampilan berkomunikasi terhadap prestasi belajar mahasiswa pada tutorial online berbasis pendekatan konstektual pada matakuliah statistika pendidikan. Junral Pendidikan, Vol.12,No.2,80-88,2011.

[29] M. Meri. Pengaruh Model Pembelajaran Kooperatif Tipe Group Investigation (MPKTGI) Terhadap Kemampuan Berkomunikasi Siswa Kelas XI pada Topik Titrasi 
Asam-Basa. Skripsi, Jurusan Kimia, FPMIPA., 2012.

[30] J. H. Payne. Reconceptualizing Social Skills in Organization: Exploring the Relationship Between Communication Competence. Job performance and supervisory roles. Journal of Leadership \& Organization Studies, Vol .11, No.2, 2005

[31] Y. Wisman. Komunikasi efektif dalam dunia pendidikan. Vol. 3, No.2, 2017.

[32] T. C, Chandra. Hambatan Komunikasi dalam Aktivitas Bimbingan Belajar antara Tutor dengan Anak kelas V SD di Bantaran Sungai Kalimas Surabaya, Jurnal E-Komunikasi, Vol. 10, No. 2, 2015.

[33] D. P. Falletehan. Hambatan Komunikasi Dalam Film "YOURS TRULY" (Analisis Semiotika Mengenai Hambatan Komunikasi yang Terdapat Dalam Film "Yours Truly”). FLOW, Vol. 2, No.16, 2016.

[34] A. Khoiruddin. Peran Komunikasi dalam Pendidikan. Tribakti : Jurnal Pemikiran Keislaman,Vol. 23, No.1, 2012.

[35] D. Mulyana. Ilmu Komunikasi: suatu pengantar. Bandung : PT. Remaja Rosda Karya, 2003.

[36] T. I. Kusumawati. Komunikasi Verbal dan Nonverbal. ALIRSYAD, Vol.6, No. 2, 2019.

[37] S. Demir. An Evaluation of Oral Language: The
Relationship between Listening, Speaking, and Self-efficacy. Universal Journal of Educational Research, Vol.5, No.9, 1457-1467, 2017

[38] J.A.W.Aomr, G.H.Seng, N. Kapol. Relationship between Willingness to Communicate in English and Classroom Environment among Libyan EFL Learners. Universal Journal of Educational Research, Vol.8, No.2, 605-610, 2020.

[39] E. Smieskova. Communication Students' Skills as a Tool of Development Creativity, and Motivation in Geometry. Universal Journal of Educational Research, Vol.5, No.1, 31-35, 2017.

[40] R. Kumar. Evaluation of Interpersonal Communication Skills of The College Students. International Journal of Marketing \& Financial Management, Vol.5, No. 6, 2017.

[41] M. Mahmud, S. Nur. Exploring Students' Learning Strategies and Gender Differences in English Language Teaching. International Journal of Language Education, Vol. 2, No. 1, 2018.

[42] M. Mahmud. Language and Gender in English Language Teaching. TEFLIN Journal, Vol.21, No.2, 2010.

[43] Rr. Rajeshwari \& M.R, John. Study on the Impact of Environmental Factors on Emotional Maturity. IOSR Journal of Business and Management, Vol.19, No.5, 2017. 